\title{
Correlation of field and experimental test data of wear in heavy commercial vehicle brake liners
}

\author{
B. SURYA RAJAN ${ }^{1, *}$, M. A. SAI BALAJI ${ }^{1}$, C. VELMURUGAN ${ }^{2}$ \\ ${ }^{1}$ Department of Mechanical Engineering, BS Abdur Rahman University, Chennai 600048, India \\ ${ }^{2}$ Department of Mechanical Engineering, Panimalar Institute of Technology, Chennai 600048, India \\ Received: 02 June 2016 / Revised: 06 August 2016 / Accepted: 06 December 2016 \\ (C) The author(s) 2017. This article is published with open access at Springerlink.com
}

\begin{abstract}
The correlation between the wear behavior of a heavy commercial vehicle (HCV) brake liner tested under controlled laboratory conditions and that in actual field conditions is investigated. A brake liner study for friction and wear is performed on an inertia brake dynamometer (IBD) at different temperatures $\left(200{ }^{\circ} \mathrm{C}\right.$, $250{ }^{\circ} \mathrm{C}$, and $300{ }^{\circ} \mathrm{C}$ ) using 6000 brake actuations in a laboratory. The total wear loss of the brake liner at three different temperatures for 6000 brake actuations in IBD is found to be $1.12 \mathrm{~mm}$. The actual field test is conducted on four different HCVs, namely, a city bus (CB), a high speed bus (HSB), a highway truck (HWT), and a tipper lorry (TL). These HCVs run at different terrain/traffic conditions and load conditions. When comparing the predicted life of the brake liner through the IBD test with the actual life of the brake liner in different HCVs, a vast difference is observed. Due to the large variation of liner life observed between the actual and predicted tests, an extensive field test is conducted. In the field test, the liner with identical formulation is fitted in the four types of HCVs. The predicted life of the liner using IBD is then correlated with the field test observation and a correlation factor is determined. Based on this correlation factor, the predicted life of the liner and the achieved life on the HCV are found to be fairly close. This study will be useful to design the friction material formulation and to predict the actual life of the brake liner for various HCVs.
\end{abstract}

Keywords: heavy commercial vehicle; wear; brake liner; correlation factor; inertia brake dynamometer; friction

\section{Introduction}

A brake liner designed/formulated for heavy commercial vehicle $(\mathrm{HCV})$ finds application in different types of vehicles, such as passenger vehicles or load carriers. Furthermore, passenger vehicles include city buses (CB) or long route intercity luxury buses (HSB). Moreover, the load carriers can be tipper lorries (TL) used in mines or trucks carrying heavy loads, which usually operate in properly maintained national highways (HWT). Brake liners used in various HCVs will have different life spans if they are used in different terrains, although the formulation is the same. A customer guideline is required to predict the life of the brake liner for a particular type of HCV. Wear life prediction of a brake lining/pad is extremely difficult, unlike other influencing parameters such as friction, fade, noise, and vibration. The wear of a friction lining (brake liner) is an extrinsic property as it depends on the pressure applied on the lining, temperature increase, speed of the drum, frequency of usage of the brakes by the driver, maintenance of the brake system, and road conditions. Wear formation in a drum brake system is shown in Fig. 1. Whenever the brake is applied, wear particles flow along the direction of rotation of the drum and also partially out of the drum. The flow of wear particles depends on the increase in temperature [1] at the drum and liner interface. The temperature increase depends on numerous parameters such as deceleration, speed,

* Corresponding author: B. SURYA RAJAN, E-mail: suryarajan.b@gmail.com 


\begin{tabular}{|c|c|c|c|}
\hline \multicolumn{4}{|l|}{ List of symbols } \\
\hline $\mathrm{WL}_{\text {Total }}$ & $\begin{array}{l}\text { Total wear loss of brake liner thickness } \\
\text { in mm after } 6000 \text { brake applications }\end{array}$ & $D_{\text {Act } 6000 \text { Brake appl.(CB) }}$ & $\begin{array}{l}\text { Actual distance travelled by } \\
\text { the city bus in } \mathrm{km} \text { for } 6000\end{array}$ \\
\hline \multirow[t]{2}{*}{$\mathrm{WL}_{\mathrm{Avg}}$} & Average wear loss of brake liner & & brake application \\
\hline & $\begin{array}{l}\text { thickness in } \mathrm{mm} \text { for } 2000 \text { brake } \\
\text { applications }\end{array}$ & $D_{\text {Act } 6000 \text { Brake appl.(HSB) }}$ & $\begin{array}{l}\text { Actual distance travelled by } \\
\text { the high speed bus in } \mathrm{km} \text { for }\end{array}$ \\
\hline \multirow[t]{2}{*}{$\mathrm{WL}_{200}$} & Wear loss of brake liner thickness for & & 6000 brake application \\
\hline & $\begin{array}{l}2000 \text { brake application at the rotor } \\
\text { temperature of } 200^{\circ} \mathrm{C}\end{array}$ & $D_{\text {Act } 6000 \text { Brake appl.(HWT) }}$ & $\begin{array}{l}\text { Actual distance travelled by } \\
\text { the highway truck in } \mathrm{km} \text { for }\end{array}$ \\
\hline \multirow[t]{2}{*}{$\mathrm{WL}_{250}$} & Wear loss of brake liner thickness for & & 6000 brake application \\
\hline & temperature of $250{ }^{\circ} \mathrm{C}$ & $L_{\mathrm{IBD}}$ & $\begin{array}{l}\text { Predicted life of the brake liner } \\
\text { in } \mathrm{km} \text { through inertia brake }\end{array}$ \\
\hline \multirow[t]{2}{*}{$\mathrm{WL}_{300}$} & $\begin{array}{l}\text { Wear loss of brake liner thickness in } \\
\text { mm for } 2000 \text { brake application at the }\end{array}$ & & $\begin{array}{l}\text { in km through inertia brake } \\
\text { dynamometers }\end{array}$ \\
\hline & rotor temperature of $300{ }^{\circ} \mathrm{C}$ & $L_{\mathrm{FO}}$ & Calculated life of the brake \\
\hline$t_{\text {usable }}$ & $\begin{array}{l}\text { Usable thickness of the brake liner } \\
\text { in } \mathrm{mm}\end{array}$ & & $\begin{array}{l}\text { liner in } \mathrm{km} \text { through field } \\
\text { observation }\end{array}$ \\
\hline \multirow[t]{2}{*}{$D_{6000 \text { Brake appl.(IID) }}$} & $\begin{array}{l}\text { Distance travelled in } \mathrm{km} \text { for } 6000 \\
\text { brake application considering }\end{array}$ & $L_{\text {Act }}$ & $\begin{array}{l}\text { Actual life of the brake liner } \\
\text { fitted in the HCV }\end{array}$ \\
\hline & laboratory standards. & $\mathrm{CF}_{(\mathrm{A}-\mathrm{B})}$ & Correlation factor based on \\
\hline \multirow[t]{2}{*}{$D_{\text {Act } 6000 \text { Brake appl.(TL) }}$} & Actual distance travelled by the & & $L_{F O}$ and $L_{\mathrm{IBD}}$ \\
\hline & $\begin{array}{l}\text { tipper lorry in } \mathrm{km} \text { for } 6000 \text { brake } \\
\text { application }\end{array}$ & $\mathrm{CF}_{(\mathrm{A}-\mathrm{C})}$ & $\begin{array}{l}\text { Correlation factor based on } \\
L_{\mathrm{Act}} \text { and } L_{\mathrm{IBD}}\end{array}$ \\
\hline
\end{tabular}

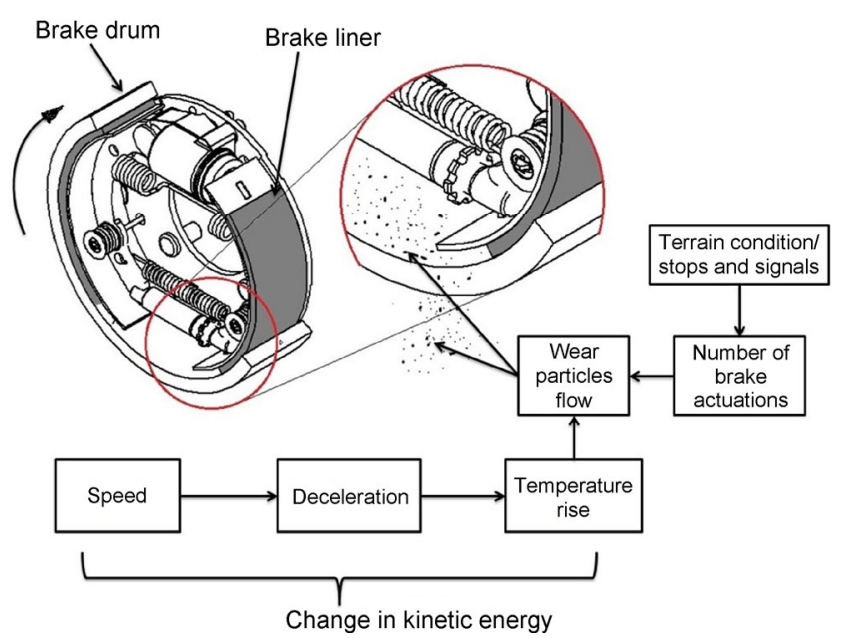

Fig. 1 Schematic diagram of wear formation in a drum brake.

pressure, and terrain/traffic conditions. A wear test is conducted in a typical schedule using an inertia brake dynamometer (IBD) by the original equipment manufacturers (OEMs) in laboratory conditions. The test results of wear conducted in IBD provide guidelines to OEMs to assess the life of the brake liner. Mostly, the same liner formulation is used in numerous $\mathrm{HCVs}$, such as CB, HSB, HWT, and TL. Usually, the predicted life using IBD does not match with the actual life of the brake liners in various HCVs [2].

Research on wear modeling and the prediction of wear life has been performed previously [3]. Therefore, to date, numerous wear models have been proposed for conflicting situations. A linear wear model was developed by Archard [4]. In this model, the wear in terms of volume per sliding distance is found in terms of wear coefficients, which can be influenced by the real contact area, material hardness, pressure distribution, and temperature increase. Alternatively, a nonlinear wear model for the brake pad assembly was developed by Rhee [5] and his influential work was followed by a few other researchers $[6,7]$. The estimation of wear of the brake blocks in a short train route with two different modeling approaches using the wear rates from the experimental pin on-disc study is discussed in Ref. [8].

A grey model was developed using the LevenbergMarquardt (LM) algorithm to predict the life of the brake pads to improve the accuracy of the life prediction 
[9]. Estimation of the life of the brake lining on the basis of controlled performance testing of analogue units was explained and the effect of the disc air duct width was calculated to obtain the brake lining service life $[2,10]$. A vehicle road test was conducted to obtain the initial braking velocity, temperature, deceleration, and brake pad wear. Based on the road (field) test, a mathematical model was developed and used for modifying the IBD test procedure to check the brake judder and noise. The test results conducted on a modified IBD test schedule coincided fairly well with the road vehicle test [11].

A micro-computer based data logging system was developed in order to study the effect of brake usage on various road surfaces under diverse conditions [12]. A mathematical model was developed to analyze the vehicle braking process with different types of road surfaces and with various vehicle parameters [13]. The formulae that were developed by most of the researchers cited above are more applicable to brake devices in railways and hoists rather than to automotive brake mechanisms, in particular to HCVs. Moreover, most of the models developed by the researchers are based on the results from the experimental studies in a controlled environment. However, the root cause of the present study is due to large variations in brake liner wear life, observed between the experimental (IBD) and field trial (actual) of a typical formulation.

In this investigation, the study of the frictional performance and wear life of a non-asbestos brake liner was conducted using IBD and compared with the actual life of a brake liner fitted in various HCVs operating over different terrain/traffic conditions and load conditions. Whenever a new brake liner formulation requires study of the wear life, the OEM cannot test it on various HCVs. However, this study can provide a few guidelines to predict the life of the brake liner for each HCV based on the IBD wear test results. Furthermore, the current work was performed to understand the wear behavior pattern of non-asbestos friction materials in the laboratory and to correlate the same data with actual field conditions.

\section{Experimental setup}

A brake liner is formulated using various types of asbestos-free fibers by a combination of Kevlar, steel wool, and glass fiber. This combination is studied for the friction performance and wear properties using the IBD shown in Fig. 2, which has a maximum braking torque capacity of $19,620 \mathrm{~N} \cdot \mathrm{m}$. The IBD test is conducted using a computerized control system as per the tailor-made test schedule. A brake liner made by a typical formulation is chosen, and the friction performance, fade/recovery, and wear properties are studied. Performance parameters such as the coefficient of friction, the braking torque generated, and the fade are not considered for the correlation study. The results pertaining to the brake liner wear are considered for this life prediction study.

\subsection{IBD}

Brake liners are tested on a double-ended IBD, as shown in Fig. 2. This IBD has a $300 \mathrm{hp} \mathrm{DC}$ drive capable of accelerating the brake drum to a speed up to $130 \mathrm{~km} / \mathrm{h}$. The inertia load can be varied from 60 to $320 \mathrm{~N}$. The test is conducted with the brake assembly and a computer-controlled air brake system capable of generating a maximum pressure of 1.0 bar to 12 bar. Parameters controlled during the test include speed, deceleration, pressure, torque, brake temperature, cooling air speed, and air temperature.

Brake liners are tested using a tailor-made test schedule to simulate the actual condition of wear test procedure, which is similar to JASO C427. This tailormade wear test procedure recommends testing the brake liners repeatedly at three temperatures, nominally $200{ }^{\circ} \mathrm{C}, 250{ }^{\circ} \mathrm{C}$, and $300{ }^{\circ} \mathrm{C}$. The temperature of the drum surface is measured by a contact type temperature sensor located exactly in the middle of the inner rotating surface and the liner temperature is measured by the thermocouple placed on the brake liner $3 \mathrm{~mm}$

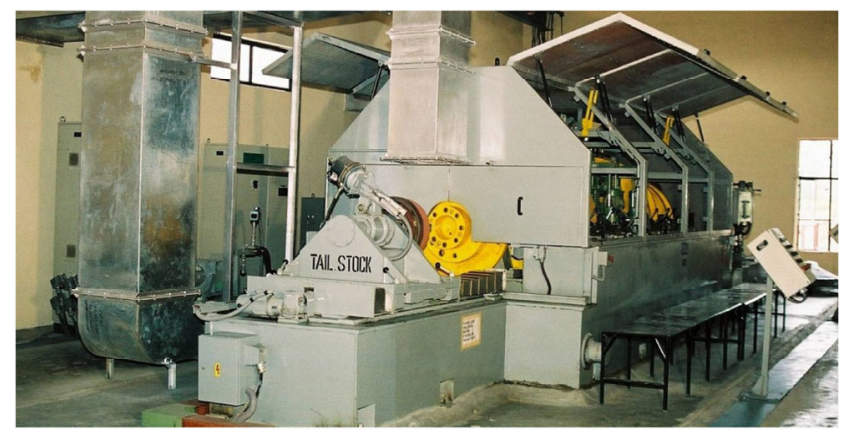

Fig. 2 Inertia brake dynamometer (IBD). 
from the drum contact surface in the radial direction [14]. After each brake actuation, the temperature is maintained at a specific value. In IBD, braking is done against an inertial mass that represents the vehicle inertia. The brake temperature is controlled and adjusted by passing air over the brake drum and liner interface at the interval of braking events using air blowers. In some cases, it is necessary to increase the initial wheel speed from 50 to $90 \mathrm{~km} / \mathrm{h}$ to obtain the $300{ }^{\circ} \mathrm{C}$ test temperature.

\subsection{Friction performance of the brake liner on the dynamometer test}

IBD has inertia masses (wheels) in its section that are rotated by the $300 \mathrm{hp}$ main drive. These inertia masses are used to simulate the kinetic energy of the running or moving HCVs. Depending upon the inertia requirement, the wheels may engage or disengage with the main drive shaft. The function of the main drive is to rotate the inertia masses to a specific speed mentioned in the schedule. After driving the inertia masses at a specified speed, the brake system starts the process of brake actuation to reduce the speed of the inertia masses to zero. The friction performance test is conducted between $35 \mathrm{~km} / \mathrm{h}$ and $110 \mathrm{~km} / \mathrm{h}$. The braking torque $(\mathrm{N} \cdot \mathrm{m})$ values are acquired at the different speeds by applying various pressures (between 1 bar and 8 bar) in the brake actuation, as shown in Fig. 3. The torque on the drive axle is monitored for different pressures and the coefficient of friction is obtained.

\subsubsection{Discussion of friction behavior of brake liner}

Although wear prediction of the brake liner is the main theme of this study, a friction performance test of the chosen brake liner formulation is initially conducted. The graph in Fig. 4 shows that the coefficient of friction continued to be relatively constant at a value of 0.4 until the pressure reached 5 bar and $12,000 \mathrm{~N} \cdot \mathrm{m}$ torque. As the pressure increases above 5 bar, the coefficient of friction decreases dramatically. This test showed that the lining materials are sensitive to pressure above 5 bar. Moreover, it is observed that for 8 bar pressure at various speeds from $35 \mathrm{~km} / \mathrm{h}$ to $110 \mathrm{~km} / \mathrm{h}$, the coefficient of friction, $\mu$, decreases with increasing speed. This reveals the inconsistency of $\mu$

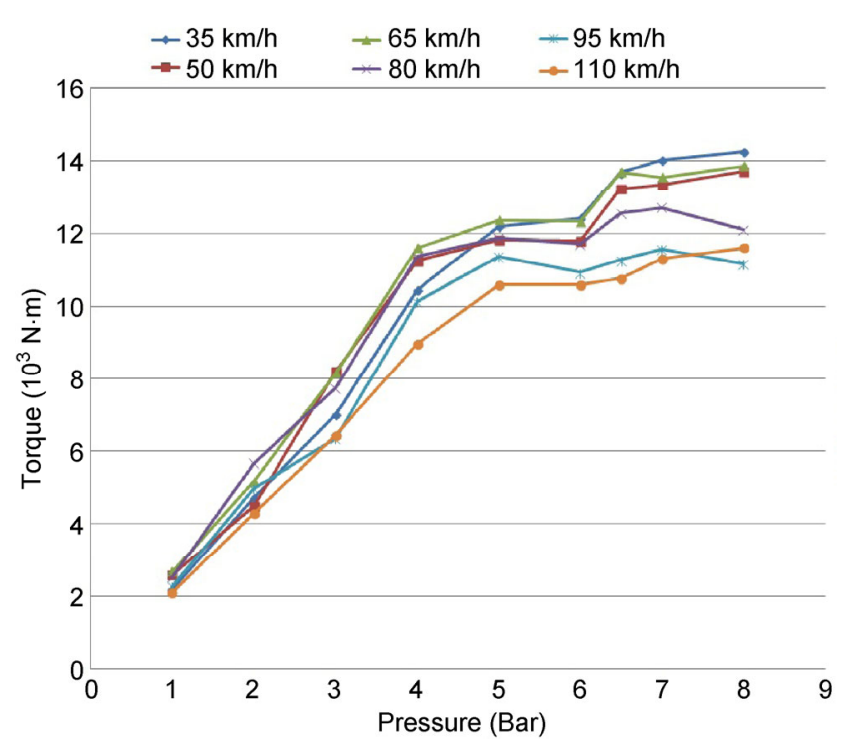

Fig. 3 Braking torque vs pressure (1-8 Bar) at different speeds of the inertia wheel $(35-110 \mathrm{~km} / \mathrm{h})$.

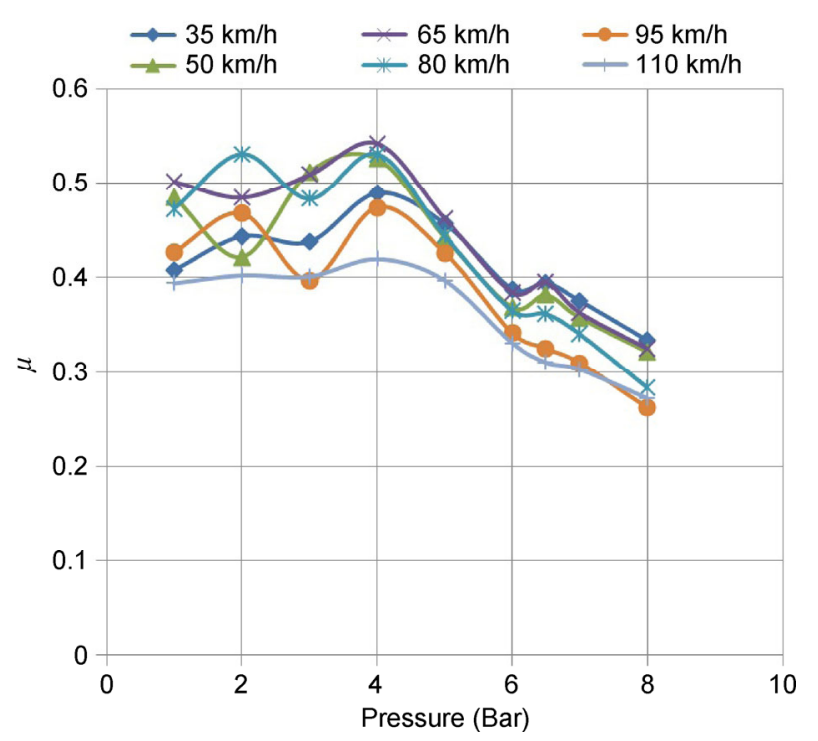

Fig. 4 Coefficient of friction (COF) vs pressure (1-8 Bar) at different speeds of the inertia wheel $(35-110 \mathrm{~km} / \mathrm{h})$.

with respect to speed. This combined effect of pressure and speed causes the temperature rise at the interface, which decreases the heat resistance components in the formulation. This temperature rise causes the destruction and reformation of the tribo layer, which is responsible for maintaining the stable coefficient of friction [1].

Hence, as observed from Fig. 4, the coefficient of friction developed by the liner is relatively consistent for different pressures and hence acceptable as per 
industrial norms. As the performance parameters correlate well with the OEM standards, it is desirable to check another important property, namely, wear as the customer wants their product to have a longer life.

\subsection{Wear test of brake liner on IBD}

After conducting the friction performance test, the test for wear is conducted using the IBD with 6000 brake actuations. The wear test is conducted for 2000 brake applications by maintaining the brake drum at three different temperatures, namely, $200^{\circ} \mathrm{C}, 250^{\circ} \mathrm{C}$, and $300{ }^{\circ} \mathrm{C}$. As per JASO C 407 (a wear test schedule for brake liners widely used in Asian countries), the wear test is conducted at $100{ }^{\circ} \mathrm{C}, 200{ }^{\circ} \mathrm{C}, 250{ }^{\circ} \mathrm{C}$, and $300{ }^{\circ} \mathrm{C}$ [14] ( $350{ }^{\circ} \mathrm{C}$ is optional, if adequate wear is not obtained). In all four types of $\mathrm{HCVs}$, the interface temperature is never close to $100{ }^{\circ} \mathrm{C}$ so this temperature is not considered in the tailor-made schedule for correlation purposes. The initial thickness of the liner is measured at 16 different points along the leading side as well as the trailing side of the brake liner. After measuring the thickness at different points on the brake liner, the wear test is conducted for 2000 brake applications at $200{ }^{\circ} \mathrm{C}$. The thickness is measured on the same point positions after 2000 brake applications for calculating the thickness loss $\left(\mathrm{WL}_{200}\right)$. The brake liner wear loss at the end of the test is determined by considering the average wear of both the leading and trailing side to be $0.257 \mathrm{~mm}\left(\mathrm{WL}_{200}=0.257 \mathrm{~mm}\right)$ and the corresponding drum wear is $0.019 \mathrm{~mm}$. Moreover, the same sequence of operation is repeated to measure the average wear loss of the brake liner at the rotor temperature of $250{ }^{\circ} \mathrm{C}\left(\mathrm{WL}_{250}\right)$ and $300{ }^{\circ} \mathrm{C}\left(\mathrm{WL}_{300}\right)$, and the results are shown in Fig. 5 . The average wear loss of the liner and drum at $250{ }^{\circ} \mathrm{C}$ is $0.372 \mathrm{~mm}\left(\mathrm{WL}_{250}=0.372 \mathrm{~mm}\right)$ and $0.024 \mathrm{~mm}$, respectively. Similarly, the average wear loss of the brake liner and brake drum at $300{ }^{\circ} \mathrm{C}$ is $0.491 \mathrm{~mm}\left(\mathrm{WL}_{300}=0.491 \mathrm{~mm}\right)$ and $0.029 \mathrm{~mm}$, respectively. The wear characteristics of the liner alone are shown in Fig. 5.

$$
\mathrm{WL}_{\text {TOTAL }}=\mathrm{WL}_{200}+\mathrm{WL}_{250}+\mathrm{WL}_{300}
$$

Hence, the total wear loss, $\mathrm{WL}_{\mathrm{TOTAL}}$ of the liner after 6000 brake applications is $1.12 \mathrm{~mm}$. The average wear loss in $\mathrm{mm}$ considering the different temperatures $\left(200{ }^{\circ} \mathrm{C}, 250{ }^{\circ} \mathrm{C}\right.$, and $300{ }^{\circ} \mathrm{C}$ ) for 2000 brake applications

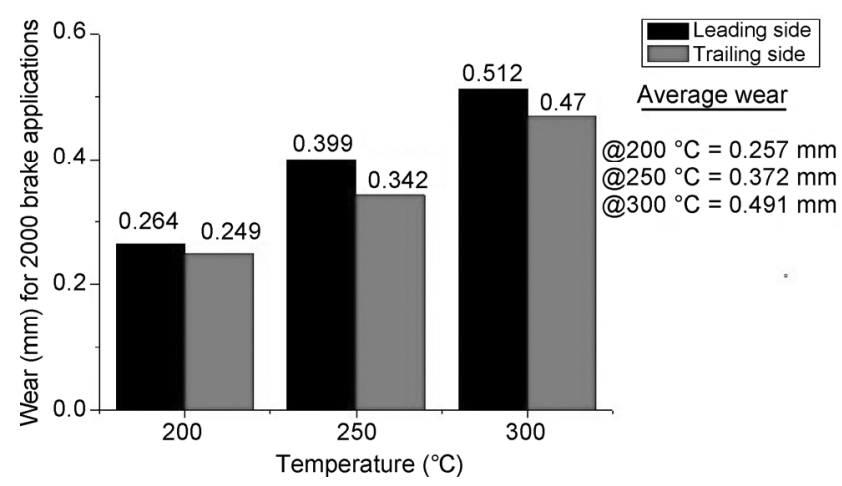

Fig. 5 Wear loss of brake liner in $\mathrm{mm}$ at $200{ }^{\circ} \mathrm{C}, 250{ }^{\circ} \mathrm{C}$, and $300{ }^{\circ} \mathrm{C}$ measured in both leading and trailing side.

has been determined as $0.373 \mathrm{~mm}$, calculated using the following equation:

$$
\mathrm{WL}_{\mathrm{AVG}}=\frac{\left(\mathrm{WL}_{200}+\mathrm{WL}_{250}+\mathrm{WL}_{300}\right)}{3}
$$

Based on industrial practices, it is understood that the vehicle will cover a minimum of $1.5 \mathrm{~km}$ for each brake application, irrespective of the speed of the vehicle. Therefore, the IBD for 6000 brake applications on the vehicle could cover a distance of $9,000 \mathrm{~km}$. Hence, it is accepted that the total wear loss of the liner is $1.12 \mathrm{~mm}$ for $9,000 \mathrm{~km}$ of travel for the vehicle. To calculate the total predicted life of the brake liner, $L_{\mathrm{IBD}}$ in $\mathrm{km}$ traveled, we use

$$
L_{\mathrm{IBD}}=\frac{\left(t_{\text {usable }}\right) \times\left(D_{6000 \text { Brake appl. (IBD) }}\right)}{\mathrm{WL}_{\mathrm{TOTAL}}}
$$

$L_{\mathrm{IBD}}$ is the expected life of the brake liner based on the IBD test result using the industry practice standards. The usable liner thickness $\left(t_{\text {usable }}\right)$ of the brake liner is $12.1 \mathrm{~mm}$. The total distance traveled for 6000 brake

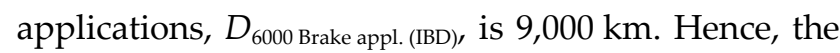
expected life of the brake liner through IBD, $L_{\mathrm{IBD}}$, is $97,232 \mathrm{~km}$. However, in a real scenario, the life of liners used in HWT is more than the expected life predicted through the IBD. In the cases of $\mathrm{CB}, \mathrm{HSB}$, and HWT, the actual life $\left(L_{\mathrm{Act}}\right)$ is very less compared to the predicted life, as shown in Table 1.

It is logical that different vehicles and road conditions cause different working modes for brakes toward the pressure applied. Some other interesting characteristics of the brake loading conditions based on field studies are the work done by the brake, number of brake 
Table 1 Comparison of liner life expected through IBD wear test \& the actual life of the liner $L_{\text {Act. }}$.

\begin{tabular}{|c|c|c|c|c|c|}
\hline $\begin{array}{l}\text { Test carried on } \\
\text { vehicles }\end{array}$ & $\begin{array}{l}\text { Dynamometer } \\
(\mathrm{km})\end{array}$ & $\begin{array}{l}\text { City bus application } \\
(\mathrm{km})\end{array}$ & $\begin{array}{l}\text { High speed bus } \\
\text { application }(\mathrm{km})\end{array}$ & $\begin{array}{l}\text { High way trucks } \\
\text { application }(\mathrm{km})\end{array}$ & $\begin{array}{c}\text { Tipper application } \\
(\mathrm{km})\end{array}$ \\
\hline $\begin{array}{l}\text { Observed liner life } \\
\text { in km }\end{array}$ & 97,232 & $28,000-32,000$ & $15,000-20,000$ & $185,000-235,000$ & $10,000-12,000$ \\
\hline $\begin{array}{l}\text { Expected through } \\
\text { IBD test, } L_{\mathrm{IBD}}\end{array}$ & & & 07022 & & \\
\hline $\begin{array}{l}\text { Average actual } \\
\text { life, } L_{\text {Act }}\end{array}$ & & 30,000 & 17,500 & 210,000 & 11,000 \\
\hline
\end{tabular}

applications per $\mathrm{km}$, deceleration, and average temperature at the interface. A detailed survey is conducted to find a number of brake applications in various transport vehicles and based on the survey, in coordination with the drivers, the brake actuations per 100 kilometers are observed and listed in Table 2. The average temperature is measured using an infrared thermometer (Nicety ST530 ), which is duly calibrated.

\section{Wear test on field}

The various categories of $\mathrm{HCV}$ for which the field tests were conducted include the following:

(1) City bus (CB) - travels on city roads characterized by very high traffic with a large number of traffic signals and stops.

(2) High speed bus (HSB)-travels on national highways and between cities.

(3) Highway trucks (HWT) - travel on highways with an average speed less than $40 \mathrm{kmph}$.

(4) Tipper lorry (TL) (Mining operations) - travels in mountain areas, roads characterized by high slopes, sharp curves, high hazardous environments (heat), and roads largely covered with mud.

In India, the road conditions have large variations. As per the OEMs suggestion, the joint field trial is always recommended to obtain the average life of the friction material formulation.

\subsection{Observations during field trial and discussion}

The wear rate comparison of the brake liners on different $\mathrm{HCV}$ applications and different locations are given in the subsequent sections.

\subsubsection{CB application}

The life of the brake liner in a CB varies from 28,000 to $32,000 \mathrm{~km}$ and $30,000 \mathrm{~km}$ on average $\left(L_{\mathrm{CB}}=\right.$ $30,000 \mathrm{~km}$ ), as mentioned in Table 1 [data obtained from Chennai and Cochin]. In the case of the CB, the frequency of brake usage ( 280 brake applications in $100 \mathrm{~km}$ traveled, ref. Table 2) is more due to heavy traffic and number of bus stops and signals. However, the speed of these buses rarely exceeds $50 \mathrm{~km} / \mathrm{h}$, with the average speed of $35-40 \mathrm{~km} / \mathrm{h}$. The gross weight (vehicle +70 passengers) of the $\mathrm{CB}$ along with the maximum passengers is around 20.80 tons. The temperature at the interface is monitored using an infrared thermometer at regular intervals. The temperature seldom exceeds $220^{\circ} \mathrm{C}$. On average, the deceleration rate is less than $0.3 \mathrm{~g}$. A higher number of brake usages accounted for the wear rate of $\mathrm{CB}$ brake liners. The life of a brake liner in Chennai is around $32,000 \mathrm{~km}$, whereas in Cochin, it is around 28,000 km due to a lot of sloppy roads.

Table 2 Observations during the field trials.

\begin{tabular}{|c|c|c|c|c|}
\hline Characteristics & City bus & High speed bus & Highway trucks & Tipper mining \\
\hline Work done by brake $(\mathrm{kJ} /(\mathrm{t} \cdot \mathrm{km}))$ & 56.4 & 39.7 & 17.6 & 94.3 \\
\hline Number of brake actuation for $100 \mathrm{~km}$ distance travel & 280 & 190 & 42 & 390 \\
\hline Number of brake actuation per km & 2.8 & 1.9 & 0.42 & 3.9 \\
\hline $\begin{array}{l}\text { Actual Distance travel for } 6000 \text { brake application, } \\
D_{\text {Act } 6000 \text { Brake appl. }}(\mathrm{km})\end{array}$ & 2143 & 3158 & 14286 & 1552 \\
\hline Deceleration rate in terms of $g$ (average) & 0.2 & 0.4 & 0.2 & 0.5 \\
\hline Temperature at interface $\left({ }^{\circ} \mathrm{C}\right)$ (average of the observed values) & 193 & 276 & 150 & 285 \\
\hline
\end{tabular}




\subsubsection{HSB application}

The life of a brake liner in a HSB varies from 15,000 to $20,000 \mathrm{~km}$ and $17,500 \mathrm{~km}$ on average $\left(L_{\mathrm{Act}(\mathrm{HSB})}=\right.$ $17,500 \mathrm{~km})$. These data were obtained from the vehicles plying between different towns in the state of Tamil Nadu and Kerala. With regard to the bus operations, as observed in the busy route between two towns, the stopping strategy employed by the drivers was found to be a major factor. The driver's attitude influences the brake temperature and controls the brake liner wear. For the field test, it is observed that the temperature increases significantly when the driver applies the brake suddenly with less stopping distance. The rate of deceleration is high (around $0.5 \mathrm{~g}$ ) and it has great influence on the temperature increase at the interface, as indicated in Fig. 1. If the driver slows down gradually with a longer stopping distance, the temperature registered is less compared to previous approaches; similar observations are reported elsewhere [15]. Moreover, the driver has to apply some panic braking due to the unexpected driving behavior of the two wheeled vehicles. A higher deceleration rate is the reason for greater wear in the case of HSB when compared to that of the CB. The number of brake applications observed in HSB for $100 \mathrm{~km}$ is 190 . The gross weight (vehicle +45 passengers) of the HSB along with the maximum passengers is around 18.90 tons.

\subsubsection{HWT application}

The life of the brake liner in a HT varies from 185,000 to $235,000 \mathrm{~km}$ and $210,000 \mathrm{~km}$ on average $\left(L_{\text {Act }(\mathrm{HWT})}=\right.$ $210,000 \mathrm{~km}$ ) [data obtained from the vehicles plying between Chennai and Mumbai, which is around $1,700 \mathrm{~km}$ ]. These HWTs normally run on express highways with minimum traffic interference. Maximum speed reached by these vehicles is around 40 to $50 \mathrm{~km} / \mathrm{h}$ because of heavy loading (up to 20 tons). They seldom use their brakes. The average number of braking applications for $100 \mathrm{~km}$ distance travel in HWT is 42. Hence, the life of the brake liner used in HWT can go more than $200,000 \mathrm{~km}$.

\subsubsection{TL application in mining}

The life of the brake liners in TLs varies from 10,000 to $12,000 \mathrm{~km}\left(L_{\mathrm{Act}(\mathrm{TL})}=11,000 \mathrm{~km}\right)$ [data obtained from the vehicles at Goa, Hubli, and Mangalore mines]. The average temperature at the interface is $250{ }^{\circ} \mathrm{C}$ due to the environment, under which these vehicles are operating. The mines usually have higher temperatures than the ambient temperature. The terrain conditions are very rough, hazardous and entirely different compared to the road conditions. The number of brake actuations is higher than other vehicles like CB, HSB, and HWT. Usually, these trucks are used to carrying double the load of buses. These factors contribute to the accelerated wear of the brake liners.

\section{Life of brake liner based on inputs from the field observation $\left(L_{\mathrm{FO}}\right)$}

In the IBD schedule, the number of brake applications, decelerations, and temperature increases follow a standard pattern. But based on the observations, the number of brake applications, decelerations, and temperature increases vary for different vehicles and terrain conditions. The actual distance traveled by the $\mathrm{HCV}\left(D_{\text {Act } 6000 \text { Brake appl. (HCV) }}\right)$ is found and tabulated in Table 2.

\subsection{Tipper lorry (TL)}

First, the case of the TL is selected as it shows a large variation to the order of the second degree. Authors substituted the observed number of brake actuations in the field study, i.e., $3.9 / \mathrm{km}$ (from Table 2) and the wear rate that occurred at $300{ }^{\circ} \mathrm{C}$, i.e., $0.491 \mathrm{~mm}$ in IBD, in order to calculate the life of the brake liner based on the field observation $\left(L_{\mathrm{FO}(\mathrm{TL})}\right)$ for the TL. The average temperature observed at the interface in the $\mathrm{TL}$ is about $285{ }^{\circ} \mathrm{C}$, which is nearer to $300{ }^{\circ} \mathrm{C}$. Hence:

$$
L_{\mathrm{FO} \text { (TL) }}=\frac{t_{\text {usable }} \times D_{\text {Act } 6000 \text { Brake appl.(TL) }}}{3 W L_{300}}
$$

The life of the brake liner, based on the field observation $L_{\mathrm{FO}}(\mathrm{TL})$, is $12,749 \mathrm{~km}$, which is very much closer to the actual life of the brake liner fitted in the TL. Similarly, the life of the brake liners based on the field observations for other types of HCVs is listed below.

\subsection{City bus (CB)}

The CB applied 280 brakes over $100 \mathrm{~km}$ (refer to 
Table 2) and the temperature increase measured in the interface is less than $200{ }^{\circ} \mathrm{C}$. Thus,

$$
\begin{aligned}
& L_{\mathrm{FO}(\mathrm{CB})}=\frac{t_{\text {usable }} \times D_{\text {Act } 6000 \text { Brake appl. (CB) }}}{3 W L_{200}} \\
& L_{\mathrm{FO}(\mathrm{CB})}=33,632 \mathrm{~km}
\end{aligned}
$$

This value is close to the actual life from the field trial, namely $30,000 \mathrm{~km}$.

\subsection{High speed bus (HSB)}

The HSB applied 190 brakes over $100 \mathrm{~km}$ (refer Table 2) and the temperature at the interface is around $300{ }^{\circ} \mathrm{C}$ due to very high deceleration involved in this route.

$$
L_{\mathrm{FO}(\mathrm{HSB})}=\frac{t_{\text {usable }} \times D_{\text {Act } 6000 \text { Brake appl.(HSB) }}}{3 \mathrm{WL}_{300}}
$$

The life of the brake liner based on the field observation $L_{\mathrm{FO} \text { (HSB) }}$ is $25,942 \mathrm{~km}$, which far exceeds the actual life from the field trial, namely, $17,500 \mathrm{~km}$. The reason for this huge difference needs a detailed investigation.

\subsection{Highway truck (HWT)}

The HWT applies 42 brakes over $100 \mathrm{~km}$ (refer to Table 2) and the temperature increase at the interface is less than $200{ }^{\circ} \mathrm{C}$. Thus,

$$
L_{\mathrm{FO}(\mathrm{HWT})}=\frac{t_{\text {usable }} \times D_{\text {Act } 6000 \text { Brake appl.(HWT) }}}{3 W L_{200}}
$$

The life of the brake liner based on the field observation $L_{\mathrm{FO}(\mathrm{HWT})}$ is $224,203 \mathrm{~km}$, which is close to the actual life from the field trial, namely $210,000 \mathrm{~km}$. (refer to Table 1).

\section{Correlation factor to correlate wear pro- perties on dynamometer and actual life}

As observed from Table 3, a similarity exists between the actual life $\left(L_{\mathrm{Act}}\right)$ of the brake liner and the expected life of the brake liner based on the inputs from the field observation $\left(L_{\mathrm{FO}}\right)$. Hence, those inputs are provided in Table 4 for modifying the test schedule. The field inputs are always necessary in considering the difference in the standard schedule (in the laboratory test) and the real operating parameters that are observed for different HCVs. For example, in the case of the TL segment, the number of brake applications is around 5.85 per $1.5 \mathrm{~km}$ where as in the IBD schedule it is assumed as only one brake application per $1.5 \mathrm{~km}$. Similarly, the normal average temperature at the interface is around $285^{\circ} \mathrm{C}$, whereas in the IBD schedule it is split up into three different temperature regimes.

Table 3 Correlation factor based on actual life $\left(L_{\text {Act }}\right)$ and life based on field observation $\left(L_{\mathrm{FO}}\right)$ vs predicted life through IBD $\left(L_{\mathrm{IBD}}\right)$.

\begin{tabular}{cccccc}
\hline & $(\mathrm{A})$ & $(\mathrm{B})$ & $(\mathrm{C})$ & \multicolumn{2}{c}{$\begin{array}{c}\text { Correlation } \\
\text { factor }(\mathrm{CF})\end{array}$} \\
\cline { 5 - 7 } $\mathrm{HCV}$ & $\begin{array}{c}L_{\mathrm{IBD}} \\
(\mathrm{km})\end{array}$ & $\begin{array}{c}L_{\mathrm{FO}} \\
(\mathrm{km})\end{array}$ & $\begin{array}{c}L_{\mathrm{Act}} \\
(\mathrm{km})\end{array}$ & $\mathrm{CF}_{(\mathrm{A}-\mathrm{B})}$ & $\mathrm{CF}_{(\mathrm{A}-\mathrm{C})}$ \\
\cline { 5 - 7 } $\mathrm{CB}$ & & 33,632 & 30,000 & 0.345 & 0.308 \\
$\mathrm{HSB}$ & & 25,942 & 17,500 & 0.266 & 0.180 \\
$\mathrm{HWT}$ & 97,232 & 224,203 & 210,000 & 2.305 & 2.150 \\
TL & & 12,749 & 11,000 & 0.131 & 0.113 \\
\hline
\end{tabular}

(A) $L_{\mathrm{IBD}}=$ Expected life of liner based on dynamometer test as per industrial practice $(\mathrm{km})$

(B) $L_{\mathrm{FO}}=$ Expected life of liner based on the inputs from field observation $(\mathrm{km})$

(C) $L_{\text {Act }}=$ Actual life of the liner $(\mathrm{km})$

Table 4 Inputs to OEM based on field trial.

\begin{tabular}{ccccccc}
\hline HCV/IBD & $\begin{array}{c}\text { Number of brake } \\
\text { actuations }\end{array}$ & Deceleration & Average speed & $\begin{array}{c}\text { Avg. number of brake } \\
\text { actuations for } 1.5 \mathrm{kms}\end{array}$ & $\begin{array}{c}\text { Deceleration } \\
\left(\mathrm{m} / \mathrm{s}^{2}\right)\end{array}$ & $\begin{array}{c}\text { Field test } \\
\text { temperature }\left({ }^{\circ} \mathrm{C}\right)\end{array}$ \\
\hline CB & High & Low & Low & 4.2 & $0.2 \mathrm{~g}$ & 193 \\
HSB & Low & High & High & 2.85 & $0.4 \mathrm{~g}$ & 276 \\
HWT & Low & Low & Low & 0.62 & $0.2 \mathrm{~g}$ & $0.5 \mathrm{~g}$ \\
TL & High & High & Low-medium & 5.85 & 150 & 285 \\
IBD & High-low & High-low & High-low & 1 & $0.3 \mathrm{~g}$ & $200,250 \& 300$ \\
\hline
\end{tabular}


The correlation factors (A-B) and (A-C) are given by

$$
\begin{gathered}
C F_{(\mathrm{A}-\mathrm{B})}=\frac{L_{\mathrm{FO}(\mathrm{HCV})}}{L_{\mathrm{IBD}}} \\
C F_{(\mathrm{A}-\mathrm{C})}=\frac{L_{\mathrm{Act}(\mathrm{HCV})}}{L_{\mathrm{IBD}}}
\end{gathered}
$$

Using Eqs. (8) and (9), the correlation factor for wear life is calculated and tabulated in Table 3. To check the dependability of the correlation factor, the brake liners were retested in the $\mathrm{CB}$ and found that the brake liner covered $30,420 \mathrm{~km}$ (using the calculation, it is $33,632 \mathrm{~km}$ ). Similarly, the brake liners were tested in the TL and found that the brake liner covered $10,200 \mathrm{~km}$ (using the calculation, it is $12,749 \mathrm{~km}$ ). The predicted wear coincided fairly closely with the measured wear. With this correlation factor,

(1) It is understood that instead of using the same formulated brake liners for different HCV applications, distinct formulations can be obtained for category of vehicles (considering the huge volume of vehicles in each category, it is quite economical).

(2) Else, it is preferable to go for the different test schedule for each vehicle category.

(3) The life of the brake liner can be predicted for the customer when fit into a particular type of $\mathrm{HCV}$.

It is observed that the usage of the brakes by the drivers, tested in the selected routes, has no correlation or resemblance with the standard test schedule followed in the industry. Yet, the formulators expect the wear rate of brake liners to coincide in real scenarios in the same way it performed in the controlled environmental conditions. Hence, some inputs for modification of the IBD schedule are provided. Even then, a larger number of varying parameters make it difficult to accurately predict the wear rate of automobile brake systems.

\section{Conclusion}

- The performance result tested on the IBD matches the respective vehicle applications. No adverse details were reported by the drivers.

- The life-span of the brake liners tested on the IBD and the field is varied. But, it can be correlated based on deceleration, maximum temperature seen and the number of stops per $100 \mathrm{~km}$ of running.
- There is no direct correlation between the wear rate tested on the IBD and the actual field conditions, but mathematical guidelines can be achieved. The IBD test is carried out to reconfirm with the same formulation, and found the wear loss reported on IBD is $1.20 \mathrm{~mm}$ (previously $1.12 \mathrm{~mm}$ ).

- The brake liners tested in the CB covered $30,420 \mathrm{~km}$ (using the calculation, it is $33,632 \mathrm{~km}$ ). Similarly, the brake liners were tested in the TL application and found that the brake liner covered 10,200 km (using the calculation, it is $12,749 \mathrm{~km}$ ). The predicted wear coincided fairly closely with the measured wear, greater than $80 \%$.

- Deceleration and the corresponding temperature increase mainly contributed to wear as all the brake liners were made by the same formulation, produced by the same manufacturer.

- The deceleration rates, maximum temperatures, and number of brake applications employed by the driver under various conditions should be documented in detail, as these affect the brake liner's life to change them even to a high order of magnitude; and can thus be used in the design stage. There is an opportunity to design materials for each application separately, to provide a higher life-span for each scenario. It is possible to improve the correlation between the test vehicle data and the IBD data; it is extremely unlikely that IBD testing will ever fully replace vehicle testing because of factors such as road conditions, driver usage of brakes, maintenance of brake systems, and auto slack adjuster functioning.

\section{Acknowledgement}

The authors are also grateful to Mr. Sanmugam, Asst. Engineer, PRTC corporation, Puducherry for providing the necessary facilities to take field trial.

Open Access: The articles published in this journal are distributed under the terms of the Creative Commons Attribution 4.0 International License (http:// creativecommons.org/licenses/by/4.0/), which permits unrestricted use, distribution, and reproduction in any medium, provided you give appropriate credit to the original author(s) and the source, provide a link to the Creative Commons license, and indicate if changes were made. 


\section{References}

[1] Ostermeyer G P. Friction and wear of brake systems. Forschung im Ingenieurwesen 66(6): 267-272 (2001)

[2] Revin A A, Tyurin S V, Fedotov V N. The way to estimate the lifetime of transport vehicle brake pad according to the results of prototype test exploitation. Transport 2: 27-29 (2007)

[3] Revin A A, Tyurin S V, Fedotov V N, The way to estimate the durability of brake pads according to the results of prototype test exploitation. Transport 8: 38-39 (2007)

[4] Archard J F. Contact and rubbing of flat surfaces. J Appl Phys 24(8): 18-28 (1953)

[5] Rhee S K. Wear mechanisms for asbestos-reinforced automotive friction materials. Wear 29(3): 391-393 (1974)

[6] Pavelescu D, Musat M. Some relations for determining the wear of composite brake materials. Wear 27: 91-97 (1974)

[7] Hohmann C, Schiffner K, Brecht J. Pad wear simulation model. SAE Technical Paper No: 1999-01-3392 (1999)

[8] Vernersson T, Lunden R. Wear of brake blocks for in-service conditions-Influence of the level of modelling. Wear 314: 125-131 (2014)

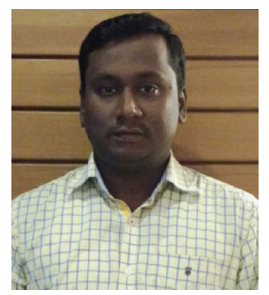

B. SURYA RAJAN. He received his bachelor degree in mechanical engineering in 2010 and master degree in engineering design in 2014 from College of Engineering Guindy,

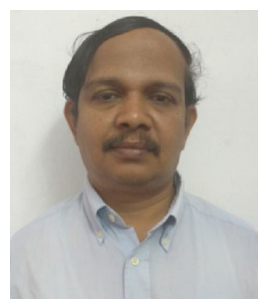

M. A. SAI BALAJI. He is an associate professor in the Department of Mechanical Engineering of BS Abdur Rahman University, Vandalur, Chennai, India. He obtained his bachelor degree in production technology

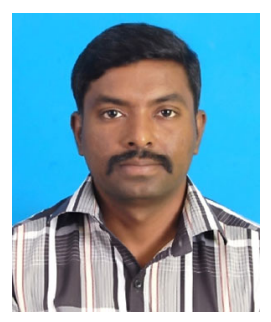

C. VELMURUGAN. He received his bachelor degree in mechanical engineering and master degree in engineering design from Anna
[9] Liu F, Liang X, Ren Q-Z, Zheng J. Life prediction of EMU brake pad based on optimized neural network and grey theory. International Journal of Digital Content Technology and its Applications 7(10): 118 (2013)

[10] Blau P J. Fifty years of research on the wear of metals. Tribol Int 30(5): 321-331 (1997)

[11] Wang Q, Qi G, Zhang G, Pu X. Study on brake durability dynamometer experimental method for brake NVH and wear. SAE Technical Paper No. 2014-01-2520 (2014)

[12] Minegishi H, Shimizu H, Wakamatsu H, and Yoshino Y. Prediction of brake pad wear/life by means of brake severity factor as measured on a data logging system. SAE Technical Paper No. 840358 (1984)

[13] Bogdevicius M, Vladdimirov O. Efficiency of a braking process evaluating the roughness of road surface. Transport 21(1): 3-7 (2006)

[14] Wear Test Procedure on Inertia Dynamomete-Brake Friction Materials-JASO C 427-83. Society of Automotive Engineers of Japan, 1983.

[15] Videla D, Fancher P. Prediction of brake temperatures on urban bus routes. UMTRI 90-32, Engineering Research Division (1990)

Anna University, Chennai, India. Currently he is a Ph.D. student in the B.S. Abdur Rahman University, Vandalur, Chennai, India. His research area includes tribology behavior study of friction composites.

from Anna University, master degree in computer aided design from Madras University and Ph.D. degree in the topic of "Effect of organic components in disc brake pad formulation in relation to fade and wear". His current research area is friction composites.

University, Chennai, India. Currently he is working as assistant professor in the Department of Mechanical Engineering, Panimalar Institute of Technology, Chennai, India. 